współczesnego tekstu mass mediów, odróżniającą go od tekstu w ogóle, jest jego wielowymiarowość, którą należy rozumieć jako połączenie niejednorodnych składowych werbalnych, wizualnych, dźwiękowych lub innych $\mathrm{w}$ jednej przestrzeni semantycznej tekstu. Charakterystyczną cechą tekstów medialnych jest również ich specyfika językowa, wynikająca $\mathrm{z}$ adresowalności do masowego odbiorcy.

Pojęcie «tekstu medialnego» nie pokrywa się i nie może być tożsame $\mathrm{z}$ językową definicją «tekstu», ponieważ jego treść wykracza poza system znaków słownych, wymaga odrębnego podejścia do jego analizy. W przypadku tekstów i tekstów medialnych jedyną wspólną cechą jest obecność dużej liczby pojęć służących do definicji tych terminów.

\title{
Literatura:
}

1. Гальперин И.Р. Текст как объект лингвистического исследования. М. : Наука, 1981.

2. Деррида Ж. О грамматологии. М. : Ad Marginem, 2000.

3. Лотман Ю.М. Текст и функция. СПб.: Искусство-СПб, 2004.

DOI https://doi.org/10.30525/978-9934-26-073-5-2-47

\section{МОВНА ПОЛІТИКА В УКРАЇНІ: ДО ПРОБЛЕМИ НАЦІОНАЛЬНОЇ ЗРІЛОСТИ}

\author{
Фаріон I. Д. \\ доктор філологічних наук, доцент, \\ професор катедри украӥнської мови \\ Національного університету «Львівська політехніка» \\ м. Львів, Україна
}

Об’єктом нашого аналізу є мовна політика України президента Володимира Зеленського та його оточення.

Під мовною політикою розуміємо систему заходів, спрямованих на утвердження статусу державної мови чи інших мов, що зумовлені рівнем мовно-національної свідомости населення країни. 3 огляду на багатостолітній період (щонайменше від половини XVII століття) ліквідації та репресій щодо української мови та ії носіїв, сучасна модель мовної політики надто далека від свідчення про національну зрілість українського суспільства і іï неможливо ідентифікувати як національну модель. 
На сьогодні на теренах України як постгеноцидної і посттоталітарної, а тепер олігархічної держави схрестилися три моделі мовної політики: колоніальна, ліберально-гібридна і начіональна [10, с. 47-93]. Якщо колоніальна модель мовної політики, крім історичного періоду ліквідації Української держави в пізньому Середньовіччі, охоплює новітній період існування України в умовах ії окупації СРСР, то ліберально-гібридна модель стала наслідком ухвалення Закону України «Про функціонування української мови як державної» 25 квітня 2019 року. Себто за час існування незалежної Української держави від 1991 року українцям як титульній нації, що становить абсолютну більшість населення країни (відповідно до останнього перепису 2001 року українців 77.8\%) [3, с. 10], не вдалося напрацювати національної мовної моделі 3 повносилим функціюванням української мови. I то більше: за час президентства В. Зеленського на тлі ліберально-гібридної моделі знову розвинулися регресивні сигнали розвороту до колоніяльної мовної моделі, основні характеристики якої подаємо в наших тезах.

1. Мова не має значення і не об'сднус. Цю тезу озвучив сам президент України в новорічну ніч 2020 року: «...не важливо як названа вулиия, бо вона освітлена та заасфальтована. < ..> немає різниці, біля якого пам'ятника ти чекаєш дівчину, в яку ти закоханий. Якщо ми бачимо майбутнє однаково, ие повинно нас об'єднати» [2]. Тобто засадничим інтеграційним чинником не $\epsilon$ мова, а всього лише візії про наше майбутнє, i не мова дає відповідь на запитання, хто я. Таким способом президент цим ментально-словесним посилом під час війни перекреслив весь історичний шлях боротьби українців за свою національну державу під проводом саме мови. В умовах колоніального поневолення України і належности ії Заходу та Сходу до різних імперій мова набирала виразного політичного характеру й була головним чинником етнонаціональної інтеграції та основним ідентифікатором українців. Саме мова у своїх надрах берегла ядро майбутньої самостійної Української Держави, територіяльно тримала іiі - i саме вона була центром усіх битв і домагань. Історія неспростовно довела причиновонаслідковий зв'язок між мовою та державою-нацією: окрема мова - це окрема держава. Проте 3 жовтня 2020 року президент в інтерв'ю європейському виданню Politico Europe заявив, що «навколо мови ніхто не буде об'єднуватися» [4].

2. «Я не мислю украӥнською мовою». Президентський мовний релятивізм (цікаво, що винятково щодо українськомовного застосування) випливає з глибинних надр мовотворення, себто мислення, для якого мова не просто одяг думок, а їхня когнітивна маніфестація, яка і викрила 
Зеленського як носія чужої когнітивної парадигми: «Я знаю українську мову. Але я не мислю нею вільно. Я перекладаю. Так, я можу з вами розмовляти украйнською мовою, але проблема в тому, що я перекладаю [7]. Ведмежу послугу для викриття Зеленського як носія радянського («совкового») способу мислення з зануренням в російський світ зробив представник політики Путіна в Україні В. Медведчук: «...необхідно припинити примусову украӥнізацію. Ви ж російськомовна людина - не робіть над собою зусиль, видаючи себе за іншу. <..> Захистіть російську і мови національних меншин. Ви заслужите повагу людей, подяку російськомовних громадян, представників інших начіональностей» [1]. Такі вимоги - найкращий підсвіт В. Зеленського як людини неукраїнського світу, що підтверджено наступною тезою.

3. «Не треба утискувати російську мову» [8]. Ця фраза від Зеленського, мовлена у березні 2019 року в статусі ще кандидата в президенти, показово засвідчила, що стрижень мовної політики ймовірного президента - це захист саме російської мови - мови його світобачення і культури, а не утвердження чи посилення державного статусу української мови, яка максимально витіснена 3 українських етнічних територій саме через агресивний наступ російської мови, себто лінгвоцид української мови через іiі заборони Росією, через приниження іiі статусу та престижу, через оголошення іiі неприродности, через явища асиміляції, через освітньо-наукові обмеження і вилучення, через демографічну політику, через привілеї для панівної російської мови та її носіїв й інші форми лінгвоциду [9, с. 25-70]. За удавано злагіднілим висловом, що «всі розмовлятимуть украӥнською мовою» [Там само] насправді сховано неоколоніяльну модель мовної поведінки, у якій державна мова не $\epsilon$ віссю розвитку. Отже, чітко висловлено філософію подальшого зросійщення України під слабким прикриттям «нема різниці» $\mathrm{i}$ «е треба утискати російської». Головне - не порушити російськомовного комфорту, оцього status quo, бо скасувати державний статус української мови політичної сили вже нема.

\section{4. «Російськомовний украӥнський націоналізм» i «російська} українська». 3 огляду на неможливіть скасувати державний статус української мови, оточення президента, крім виразних атиукраїнських законодавчих ініціятив у парламенті, як наприклад, «старе новаторство» нардепа М. Бужанського про навчання мовами національних меншин по всій вертикальні чи скасування штрафів у мовному законі за недотримання мовного режиму, починає продукувати абсурдні ідеї про «російськомовний український націоналізм» (А. Аваков) [6] чи «українську російську мову» як «неусвідомлене багатство» 
(Ю. Мендель) [5]. Такі вигадливо-витіюваті думки про мову, попри їхню абсурдність та дражливість, несуть у собі позитивний сигнал, позаяк обмежити державний статус української мови прийнятними методами колоніяльної мовної моделі надто важко. Саме звідси безпорадні термінологічні оксюморони про «російськомовного націоналіста» $\mathrm{i}$ «українську російську мову», що не можуть бути новою смисловою якістю ні за суттю, ні політично, а хіба свідчать про агонію ідеології «рускава міра» як останньої надії втримати Україну на російській орбіті.

Висновки. Мовний світогляд В. Зеленського - це відображення колоніальної мовно-національної свідомости значної частини населення країни. Основне завдання В. Зеленського та його поплічників полягає у віднайденні механізмів обмеження державного статусу української мови і повернення до колоніальної мовної моделі. Задля цього нова влада озвучує в суспільстві такі основні тези: мова - це штучне і непринципове питання зі сфери «какая разніца», одначе це аж ніяк не стосується російської мови, яку сором'язливо приховано за постійними розмовами про мови нацменшин; українська мова державна, але без дотримання державного статусу через закон, бо закон потрібен лише для застосування російської мови; питання української мови - це питання приватного бажання й часу, а не чинного законодавства - i це не чинник державної безпеки й основний інструмент впливу державиагресора на свідомість постколоніяльного українського суспільства, а перешкода для реалізації ще однієї Росії на території України.

\section{Література:}

1. Віктор Медведчук звернувся з відкритим листом до Володимира Зеленського. Режим доступу: https://glavcom.ua/country/society/viktormedvedchuk-zvernuvsya-z-vidkritim-listom-do-volodimira-zelenskogo-6870 30.html, (дата звернення 15.06.2020).

2. Давайте кожен чесно відповість на важливе питання: хто я. Новорічне привітання президента Зеленського. Режим доступу: https://tsn.ua/politika/davayte-kozhen-chesno-vidpovist-na-vazhlive-pitannyahto-ya-novorichne-privitannya-prezidenta-zelenskogo-1468050.html (дата звернення 31.12.2019).

3. Етнонаціональна структура українського суспільства. Довідник. К.: Наукова думка, 2004. 342 с.

4. Інтерв'ю Президента України європейському виданню Politico Europe. Режим доступу: https://www.president.gov.ua/news/intervyuprezidenta-ukrayini-yevropejskomu-vidannyu-politico-64289 (дата звернення 27.10.2020). 
5. Мендель заявила, що в Україні є «українська» російська мова. Режим доступу: https://www.unian.ua/society/movne-pitannya-mendelzayavila-shcho-v-ukrajini-ye-ukrajinska-rosiyska-mova-novini-ukrajini-11 376679.html?utm_source=social\&utm_medium=share\&utm_campaign=site\& fbclid=IwAR2QfMif_t19F9ev4lTAsbqtX47tvcfRnazhkBnKndHyv5_lmXbeiv H5vNA, (дата звернення 04.04.21).

6. «Ми повинні вітати розвиток нашої російської мови, якою розмовляють мільйони українців, i давати ій можливість вільно розвиватися». Режим доступу: https://www.radiosvoboda.org/a/newsavakov-rosiyska-mova-rozvytok/31178355.html (дата звернення 30.03.21).

7. «Не думаю нею вільно»: Зеленський висловився про українську мову. Режим доступу: https://intermarium.com.ua/ne-dumayu-neyu-vilnozelenskyj-vyslovyvsya-pro-ukrayinsku-movu/_(дата звернення 10.03.20).

8. «Не треба утискувати!». Режим доступу: https:// www.obozrevatel.com/ukr/politics/ne-treba-tisnuti-zelenskij-zhorstkozastupivsya-za-rosijsku-movu.htm (дата звернення 22.03.2019).

9. Радевич-Винницький Ярослав, Іванишин Василь. Мова і нація. Львів: Апріорі, 2012. 210 с.

10. Фаріон Ірина. Законодавче поле української мови: колоніяльна, ліберально-гібридна і національна мовні моделі (1989-2019 рр.). Украӥнська реальність крізь призму терміна. Львів: Видавництво Львівської політехніки, 2019. С. 47-93.

DOI https://doi.org/10.30525/978-9934-26-073-5-2-48

\title{
ОТРАЖЕНИЕ КАТЕГОРИИ АДРЕСАНТА В РЕЧЕВОМ СОБЫТИИ МАССМЕДИЙНОГО ПОЛИТИЧЕСКОГО ДИСКУРСА УКРАИНЫ
}

\author{
Филатенко И. А. \\ кандидат филологических наук, \\ доиент кафедры соииально-гуманитарных дисииплин \\ Киевского медицинского университета \\ г. Киев, Украина
}

Наблюдения авторитетных исследователей языка [5], [8], указывающих на существование особого типа события (далее - С.), которое нашло отражение в тексте («текстовое событие» в терминологии В. 3. Демьянкова [5]), а также размышления философов, социологов, 